\title{
The genus Lepraria (Stereocaulaceae, lichenized Ascomycota) in Belarus
}

\author{
Andrei Tsurykau ${ }^{1,2}$, Vladimir Golubkov ${ }^{3} \&$ Pavel Bely $^{4}$ \\ ${ }^{1}$ Department of Biology, F. Skorina Gomel State University, Sovetskaja st. 104, 246019 Gomel, Belarus. \\ E-mail: tsurykau@gmail.com \\ ${ }^{2}$ Department of Ecology, Botany and Nature Protection, Institute of Natural Sciences, Samara National Research \\ University, Moskovskoye shosse 34, 443086 Samara, Russia \\ ${ }^{3}$ Department of Biology and Ecology, Ya. Kupala Grodno State University, Dovatora st. 3/1, 230015 Grodno, Belarus. \\ E-mail: vgolubkov@tut.by \\ ${ }^{4}$ Laboratory of Ecological Physiology of Plants, Central Botanical Garden of the National Academy of Sciences of the \\ Republic of Belarus, Surganova 2B, 220012 Minsk, Belarus. E-mail: pavel.bely@tut.by
}

\begin{abstract}
Based on an examination of 360 herbarium specimens of the genus Lepraria, this study deals with their morphology, secondary chemistry, habitat requirements and distribution in Belarus. Nine taxa have been accepted, of which L. ecorticata, L. finkii and L. rigidula are new to the country. L. incana appears to be the commonest species in the country ( $48 \%$ of the studied specimens).
\end{abstract}

Keywords: Stereocaulaceae, secondary metabolites, chemotaxonomy, lichen distribution, lichen ecology

\section{INTRODUCTION}

The circumscription of lichen-forming fungi has traditionally been based on their morphological, chemical and ecological features, but many species reproduce through the dispersal of lichenized diaspores and never form fruiting bodies. Historically, asexually reproducing crustose taxa were treated together as Lichenes imperfecti (Reichenbach, 1841; Poelt, 1958; Tehler, 1996) although they do not represent a monophyletic group (e.g. Lendemer, 2013). Recent advances in molecular biology and chemistry of secondary lichen metabolites has helped systematists to classify members of this group (e.g. Leuckert et al., 1995; Ekman \& Tønsberg, 2002; Nelsen et al., 2008; Hodkinson \& Lendemer, 2013; Lendemer \& Hodkinson, 2013), but many aspects of their biology and taxonomy remain poorly understood and critically understudied.

According to Lendemer (2013) Lepraria Ach. is "the most unusual member" of the sterile lichen crusts. This genus is comprised of c. 60 species with a leprose thallus almost entirely composed of soredia (Saag et al., 2009). These taxa are diverse both chemically and morphologically. Although the genus has been comprehensively revised during recent decades in some countries
(Laundon, 1992; Tønsberg, 1992; Lohtander, 1994; Kukwa, 2006b; Baruffo et al., 2006; Lendemer, 2013), there are many countries where our knowledge of Lepraria is still incomplete.

In Belarus, information on lichens goes back to the end of the 18th century, when Gilibert (1781) reported 42 species including Lichen incanus. Since then, leprose lichen species have been much neglected, there being only a few records of Lepraria incana s.1. (Ges', 1960; Golubkov \& Shukanov, 1983; Golubkov, 1988; 2011), and the genus itself was often missing in lichenological summaries (fide Gorbach, 1973). Only a few reliable records of Belarusian Lepraria, confirmed by thin-layer chromatography, have been recorded in the literature (Czyżewska, 2005; Golubkov \& Kukwa, 2006; Tsurykau et al. 2014). As a result, only six taxa have been recorded from the country, namely $L$. eburnea J.R. Laundon, L. elobata Tønsberg, L. incana (L.) Ach. s.str., L. jackii Tønsberg, L. neglecta (Nyl.) Erichsen and L. vouauxii (Hue) R.C. Harris. The aim of this study is to extend our knowledge of the range of taxa within the genus Lepraria, together with information on their morphology, chemistry, ecology and distribution in Belarus. 


\section{MATERIAL AND METHODS}

This study is based on material in GSU, GRSU, MSK, MSKH and MSKU herbaria (Thiers, [continuously updated]), which include collections made by the authors. Lichen morphology was studied under a stereomicroscope, Nikon SMZ-745, and secondary lichen compounds were studied with TLC using aluminum plates Macherey-Nagel Alugram Sil G UV254 in solvent system $\mathrm{C}$ according to the methods of Orange et al. (2001). In all, 360 specimens have been studied, most of which were collected by the authors; when more than one species was present in a packet, each taxon was counted as a separate specimen. Due to insufficient or indecipherable data on the labels, we were unable to interpret the ecology of eight specimens. Morphological descriptions and chemical data given are based exclusively on Belarusian material.

\section{RESULTS}

Nine taxa have been found in the material examined, of which three species, Lepraria ecorticata (J.R. Laundon) Kukwa, L. finkii (B. de Lesd.) R.C. Harris and L. rigidula (B. de Lesd.) Tønsberg, are new to Belarus. Five taxa, L. eburnea, L. ecorticata, $L$. neglecta, $L$. rigidula and $L$. vouauxii, are known only from a very few locations and may be endangered in Belarus. L. incana appears to be the most widely distributed and commonest species in the country.

\section{THE SPECIES}

LEPRARIA EBURNEA J.R. Laundon

Morphology: Thallus leprose, thick, finkii-type, whitish to greenish-white, old sample with pink tint (caused by the presence of alectorialic acid), thallus margin diffuse to delimited, medulla white, soredia with short projecting hyphae.

Chemistry: Alectorialic and protocetraric acids.

Ecology: According to Kukwa (2006b), L. eburnea inhabits a wide range of basic to moderately acidic substrata; in Belarus the species was found on soil (1 specimen) and Alnus glutinosa (1). Golubkov \& Kukwa (2006) reported Quercus robur as a substrate for the third known specimen.

Distribution: In Belarus it is a rare species (Fig 1A), most probably under-collected, being pre- viously known from one locality in Belovezhskaja Puscha National Park (Golubkov \& Kukwa, 2006); two new discoveries are given below. $L$. eburnea has been reported from Europe, Asia, North America (including Greenland) and Australia (Güvenç and Oztürk, 1999; Saag et al., 2009; Lendemer, 2013; McCarthy, 2015).

Notes: The species is well characterized by the projecting hyphae on its soredia and the presence of alectorialic acid. Specimens of L. eburnea are often morphologically similar to L. finkii, but differ chemically. The species has similar chemistry to L. neglecta, but the latter differs by its granular and coarse thallus; it also grows in places exposed to sun and rain (Tønsberg, 1992; Golubkov \& Kukwa, 2006).

Specimens examined: Brest region, Kamenets district, Belovezhskaja Puscha National Park, KorolevoMostovskoje forest, $52^{\circ} 36^{\prime} \mathrm{N}, 2^{\circ} 46^{\prime} \mathrm{E}, 159 \mathrm{~m}$, on Alnus glutinosa, 12.07.1981, leg. V. Golubkov (MSK); Grodno region, Grodno district, the city of Grodno, Rumlevo wooded park, $53^{\circ} 39^{\prime} \mathrm{N}, 23^{\circ} 51^{\prime} \mathrm{E}, 161 \mathrm{~m}$, slope of a ravine, on soil, 23.08.2008, leg. V. Golubkov (GRSU). Number of specimens examined: 2 .

\section{LEPRARIA ECORTICATA (J.R. Laundon) Kukwa}

Morphology: Thallus leprose, irregular, powdery, thick, whitish-green or bluish-green with yellowish tint, thallus margin diffuse, medulla absent, soredia separated from each other, with no projecting hyphae. Three specimens perfectly matched descriptions of the species (see Kukwa, 2006a and literature cited therein), while the fourth sample had a very thick thallus with a well-developed medulla which was preliminarily asigned to L. ecorticata.

Chemistry: Usnic acid and zeorin.

Ecology: According to Kukwa (2006a) and Flakus \& Kukwa (2007), L. ecorticata usually grows on stones, very rarely on tree bark; in Belarus it inhabits the bark of Populus tremula (2 specimens), Tilia cordata (1) and Fraxinus excelsior (1).

Distribution: New to Belarus, where it is known from four localities, mainly in the southern part of the country (Fig. 1B). World distribution data on $L$. ecorticata are scarce; it has rarely been reported from Europe, Asia and South America (Kukwa, 2006a; Flakus \& Kukwa, 2007). The species has been tentatively excluded from North American lichen check-list (Lendemer \& Hodkinson, 2013). 




Fig. 1. Distribution of Lepraria eburnea (A), $L$. ecorticata (B), L. elobata (C), L. finkii (D) and L. incana $(\mathrm{E})$ in Belarus.

Notes: Phylogenetic affinities of the crustose leprose taxa which produce usnic acid has been frequently questioned (e.g. Laundon, 1992; Sipman, 2003; Nelsen et al., 2008; Lendemer \& Hodkinson, 2013; Bungartz et al., 2013). Recent molecular phylogenetic studies (Nelsen et al., 2008; Lendemer \& Hodkinson, 2013) were the basis for transferring several taxa from Lepraria to other genera, and only three such species currently remain within Lepraria, namely $L$. ecorticata, L. leuckertiana (Zedda) L. Saag and $L$. straminea Vain. Lendemer \& Hodkinson (2013) assumed that $L$. ecorticata was taxonomically heterogeneous, and unites biogeographically discordant elements with an aggregate thallus containing usnic acid and zeorin. However, we tentatively apply the name "Lepraria ecorticata" to Belarusian material until further European populations have been studied.

The species has a similar chemistry to $L$. leuckertiana and $L$. straminea, but the former differs by its wooly, thick and stratified thallus, while the latter has a granular, L. neglecta-like thallus and grows in Antarctica (Øvstedal \& Lewis Smith, 2001; Kukwa, 2006a; Saag et al., 2009). In Belarus, L. ecorticata may be mistaken for Lecanora compallens Herk \& Aptroot and $L$. expallens Ach., but these species have a prothallus and delimited soralia at least in the young parts of the thalli (Kukwa, 2006a).

Specimens examined: Brest region, Pruzhany district, Belovezhskaja Puscha National Park, Khvoinik forest, $4 \mathrm{~km}$ NE of Khvoinik village, $52^{\circ} 43^{\prime} \mathrm{N}, 23^{\circ} 59^{\prime} \mathrm{E}$, $170 \mathrm{~m}$, ash forest, on Fraxinus excelsior, 27.07.1983, leg. V. Golubkov (GRSU); Gomel region, Dobrush district, Dobrush forest, $4 \mathrm{~km} \mathrm{~N}$ of Uborok village, $52^{\circ} 29^{\prime} \mathrm{N}, 31^{\circ} 30^{\prime} \mathrm{E}, 137 \mathrm{~m}$, spruce forest, on Populus tremula, 26.07.2010, leg. P. Bely (MSKH-2867); Zhitkovichi district, Pererovo forest, $52^{\circ} 02^{\prime} \mathrm{N}, 27^{\circ} 58^{\prime} \mathrm{E}$, $134 \mathrm{~m}$, aspen forest, on Populus tremula, 18.05.1973, leg. O. Shakhrai (GSU); Grodno region, Grodno district, the city of Grodno, Stanislavovo Park, $53^{\circ} 41^{\prime} \mathrm{N}$, $23^{\circ} 50^{\prime} \mathrm{E}, 131 \mathrm{~m}$, on Tilia cordata, 15.04.2004, leg. A. Khartanovich (GRSU).

Number of specimens examined: 4.

\section{LEPRARIA ELOBATA Tønsberg}

Morphology: Thallus leprose, irregular, powdery, thin, whitish to bluish-grey, thallus margin diffuse, medulla absent, soredia separated from each other, without projecting hyphae.

Chemistry: Atranorin, constictic acid, cryptostictic acid, stictic acid, zeorin.

Ecology: In Belarus, L. elobata was found almost exclusively in coniferous woodlands $(98.4 \%$ of the studied material) of varying humidity, from wet boggy areas to dry pine stands, growing on Pinus sylvestris (32 specimens), Picea abies (21), Betula pendula (4), Quercus robur (4) and lignum (2).

Distribution: Lepraria elobata is widely distributed in Belarus (Fig. 1C). The species has a boreal distribution, being known from Europe, North America (including Greenland) and in Asia from the Russian Far East (Saag et al., 2009; Urbanavichus, 2010; Lendemer, 2013). Two Asian specimens from Buryatia (Russia), published as L. elobata by Kharpukhaeva \& Khanin (2012), should be considered with caution as the specimens were claimed to contain atranorin and lepraric acid, and atranorin, connorstictic acid and conporphyrilic acid, respectively.

Notes: In Belarus, only L. finkii has a similar chemistry to L. elobata, but the former differs by its woolly, thick thallus with long projecting hyphae. 
Selected specimens examined: Brest region, Stolin district, $5 \mathrm{~km} \mathrm{NW}$ of Stolin town, $51^{\circ} 56^{\prime} \mathrm{N}, 26^{\circ} 49^{\prime} \mathrm{E}$, $139 \mathrm{~m}$, spruce forest, on Quercus robur, 06.08.2010, leg. P. Bely, (MSKH-3002); Gomel region, Gomel district, Dolgolesskoje forest, $0.5 \mathrm{~km} \mathrm{NE}$ of Dolgolesie village, $52^{\circ} 16^{\prime} \mathrm{N}, 30^{\circ} 44^{\prime} \mathrm{E}, 134 \mathrm{~m}$, pine forest, on Pinus sylvestris, 07.08.2013, leg. A. Tsurykau (GSU-1848); Grodno region, Lida district, $2 \mathrm{~km}$ S of Tarnovo village, $53^{\circ} 46^{\prime} \mathrm{N}, 25^{\circ} 08^{\prime} \mathrm{E}, 142 \mathrm{~m}$, pine forest, on Pinus sylvestris, 25.01.2007, leg. N. Matjas (GRSU); Minsk region, Stolbtsy district, $2.5 \mathrm{~km} \mathrm{NE}$ of Kletische village, $53^{\circ} 50^{\prime} \mathrm{N}, 26^{\circ} 19^{\prime} \mathrm{E}, 141 \mathrm{~m}$, spruce forest, on lignum, 08.09.2010, leg. P. Bely (MSKH-3242); Mogilev region, Bobruisk district, $1 \mathrm{~km} \mathrm{NW}$ of Sychkovo village, $53^{\circ} 13^{\prime} \mathrm{N}, 29^{\circ} 07^{\prime} \mathrm{E}, 162 \mathrm{~m}$, spruce forest, on Picea abies, 21.11.2010, leg. P. Bely (MSKH-5702); Vitebsk region, Lepel district, $1.5 \mathrm{~km} \mathrm{NE}$ of Lepel town, $54^{\circ} 53^{\prime} \mathrm{N}, 28^{\circ} 44^{\prime} \mathrm{E}, 144 \mathrm{~m}$, spruce forest, on Picea abies, 14.07.2010, leg. P. Bely (MSKH-5695).

Number of specimens examined: 65.

\section{LEPRARIA FINKII (B. de Lesd.) R.C. Harris}

Morphology: Thallus leprose, woolly, soft, thick, light-green to greyish, sometimes becoming partly detached from the substratum, thallus margin diffuse to delimited, sometimes with sublobes, medulla well developed, white, soredia often grouped in consoredia, loosely packed, with usually long projecting hyphae.

Chemistry: Atranorin, constictic acid, cryptostictic acid, stictic acid, zeorin.

Ecology: In Belarus the species prefers wet spruce forests (21 specimens), but some specimens were found in broadleaved forests or in open situations. Lepraria finkii inhabits a wide range of substrata, namely bark (23 specimens), soil (4), wood (3) and concrete (1); corticolous samples were collected from Picea abies (10), Alnus glutinosa (4), Betula pendula (2), Quercus robur (2), Acer platanoides (2), Pinus sylvestris (2) and Sorbus aucuparia (1). It would appear that L. finkii is the most indifferent species within the genus in Belarus in terms of substrate selectivity, as noted by Kukwa \& Flakus (2009) (sub. L. lobificans) and Lendemer (2013).

Distribution: Lepraria finkii (sub. L. lobificans) is a widespread cosmopolitan lichen, reported from all continents, except Antarctica (Sipman, 2004; Saag et al., 2009; Kukwa \& Flakus, 2009; McCarthy, 2015); new to Belarus, being common in the country (Fig. 1D).

Notes: This taxon was previously known as $L$. lobificans auct. (Laundon, 1992) until Lendemer (2010; 2013) resolved its status and adopted the name $L$. finkii.
The species is highly characteristic due to its chemistry (atranorin, zeorin, and stictic acid complex) and morphology (cottony thallus having long projecting hyphae).

Selected specimens examined: Brest region, Baranovichi district, $1 \mathrm{~km} \mathrm{~N}$ of Baranovichi town, $53^{\circ} 10^{\prime} \mathrm{N}, 26^{\circ} 00^{\prime} \mathrm{E}, 186 \mathrm{~m}$, spruce forest, on concrete, 27.08.2009, leg. P. Bely (MSKH-928); Gomel region, Staro-Djatlovichskoje forest, $1.5 \mathrm{~km} \mathrm{NE}$ of Chkalovo village, $52^{\circ} 17^{\prime} \mathrm{N}, 30^{\circ} 51^{\prime} \mathrm{E}, 119 \mathrm{~m}$, pine forest, on Pinus sylvestris, 31.07.2013, leg. A. Tsurykau (GSU-1734); Grodno region, Volkovyssk district, close to Savichy village, $53^{\circ} 09^{\prime} \mathrm{N}, 24^{\circ} 37^{ } \mathrm{E}, 218 \mathrm{~m}$, on soil, 24.05.2006, leg. V. Golubkov (GRSU); Minsk region, Stolbtsy district, $1 \mathrm{~km} \mathrm{NE}$ of Kroman' lake, $53^{\circ} 43^{\prime} \mathrm{N}, 26^{\circ} 19^{\prime} \mathrm{E}$, $153 \mathrm{~m}$, spruce forest, on lignum, 12.09.2010 leg. P. Bely (MSKH-3555); Mogilev region, Bobruisk district, $1 \mathrm{~km}$ NW of Sychkovo village, $53^{\circ} 13^{\prime} \mathrm{N}, 2^{\circ} 07^{\prime} \mathrm{E}, 162$ m, spruce forest, on Picea abies, 21.11.2010, leg. P. Bely (MSKH-5262); Vitebsk region, Lepel district, Domzheritsy forest, close to Domzheritsy village, $54^{\circ} 45^{\prime} \mathrm{N}, 28^{\circ} 19^{\prime} \mathrm{E}, 167 \mathrm{~m}$, spruce forest, on Alnus incana, 19.04.2010, leg. P. Bely (MSKH-3894).

Number of specimens examined: 35.

LEPRARIA INCANA (L) Ach.

Morphology: Thallus leprose, powdery, greyishgreen, blue-green or greyish-blue, margin diffuse, medulla rarely present, thin, soredia diffuse.

Chemistry: Divaricatic acid and zeorin, sometimes accompanied by atranorin.

Ecology: The species is mostly found in conifer forests (96\% of the studied material) of varying illumination and humidity. The frequency on different substrata is as follows: Picea abies (88 specimens), Pinus sylvestris (58), Quercus spp. (12), wood (3), Populus tremula (3), Alnus glutinosa (2), Abies alba (1), Acer platanoides (1), Betula pendula (1), Pyrus communis (1) and Tilia cordata (1). The species inhabits mostly acidic substrata, as noted for Latvia by Mežaka et al. (2012).

Distribution: This is the most widely distributed and commonest species within the genus in Belarus, with scattered localities in the northern and eastern parts of the country (Fig. 1E). According to Saag et al. (2009), L. incana is a cosmopolitan lichen, being reported from all continents, except Arctic and Antarctic regions. However, as discussed by Lendemer (2011), this species is absent in North America as sequences derived from its populations of $L$. incana have revealed two semi-cryptic species, namely $L$. 
hodkinsoniana Lendemer and L. pacifica Lendemer. This indicates that the taxonomy of the species requires further molecular studies as additional species might be hidden under this name.

Notes: The species of Lepraria producing divaricatic acid has been recently overviewed by Lendemer (2011), revealing that L. incana can be heterogeneous (see above).

Selected specimens examined: Brest region, Pruzhany district, Belovezhskaja Puscha National Park, Nikorskoje forest, $5 \mathrm{~km} \mathrm{SE}$ of Babinets village, $52^{\circ} 37^{\prime} \mathrm{N}$, $24^{\circ} 03^{\prime} \mathrm{E}, 172 \mathrm{~m}$, oak forest, on Abies alba, 29.07.1983, leg. V. Golubkov (MSK); Gomel region, Buda-Koshelevo district, Chebotovichi forest, $0.5 \mathrm{~km} \mathrm{SW}$ of Klenovitsa village, $52^{\circ} 36^{\prime} \mathrm{N}, 30^{\circ} 19^{\prime} \mathrm{E}, 139 \mathrm{~m}$, pine forest, on Pinus sylvestris, 13.07.2013, leg. A. Tsurykau (GSU-1608); Grodno region, Grodno district, the city of Grodno, bank of the Gorodnichanka river, $53^{\circ} 40^{\prime} \mathrm{N}, 23^{\circ} 49^{\prime} \mathrm{E}$, $127 \mathrm{~m}$, on Acer platanoides, 23.03.2004, leg. A. Khartanovich (GRSU); Minsk region, Stolbtsy district, $2.5 \mathrm{~km}$ NE of Kletische village, 53⒌ $50^{\prime} \mathrm{N}, 26^{\circ} 19^{\prime} \mathrm{E}, 147$ $\mathrm{m}$, spruce forest, on Picea abies, 08.09.2010, leg. P. Bely (MSKH-3255); Mogilev region, Bobruisk district, $1 \mathrm{~km}$ NW of Sychkovo village, $53^{\circ} 13^{\prime} \mathrm{N}, 2^{\circ} 07^{\prime} \mathrm{E}, 163$ $\mathrm{m}$, spruce forest, on lignum, 21.11.2010 leg. P. Bely (MSKH-2626); Vitebsk region, Lepel district, $0.5 \mathrm{~km}$ $\mathrm{NE}$ of Domzheritsy village, $54^{\circ} 45^{\prime} \mathrm{N}, 28^{\circ} 19^{\prime} \mathrm{E}, 190 \mathrm{~m}$, spruce forest, on Picea abies, 08.10.2009, leg. P. Bely (MSKH-1940).

Number of specimens examined: 172 .

LEPRARIA JACKII Tønsberg VAR. JACKII

Morphology: Thallus leprose, powdery, whitishgreen to greenish, subthalline hyphae white, soredia diffuse, fine, with or without short projecting hyphae.

Chemistry: atranorin, jackinic and angardianic/ roccellic acids.

Ecology: In Belarus, L. jackii grows only in forest conditions, almost exclusively in coniferous woodlands (67 specimens). It prefers acidic substrata, mostly bark of Pinus sylvestris (36), Picea abies (27) and Quercus robur (2), but also occurs on lignum (3). A similar ecology was also reported for Poland by Kukwa (2006b).

Distribution: The species was previously included in "The red list of lichens of Pripyatsky National Park" (Golubkov 2011). The current study reveals that $L$. jackii is widely distributed in Belarus, but occurs in scattered localities in the eastern and northern parts of the country (Fig. 2A). The species is common in Scots pine forests of varying age, humidity and light condi- tions, except for very young pine stands. L. jackii has been reported from Europe, Asia, North America and Australia, and mostly confined to the boreal zone (Saag et al., 2009; Lendemer, 2013; McCarthy, 2015).

Notes: Until 2002, only three species of Lepraria containing fatty acids and atranorin were known to occur in Europe: L. borealis Loht. \& Tønsberg, L. jackii and L. rigidula (B. de Lesd.) Tønsberg (Tønsberg, 1992; Lohtander, 1994). Since then, much attention has been paid to the taxonomy and chemistry of this group, and six species have been newly described, namely $L$. bergensis Tønsberg, $L$. celata Slaviková, $L$. granulata Slav.-Bay., L. humida Slavíková \& Orange, L. sylvicola Orange and $L$. toensbergiana Bayerová \& Kukwa (Tønsberg, 2002; Bayerová et al., 2005; Slavíková-Bayerová \& Orange, 2006; Slaviková-Bayerová \& Fehrer, 2007). However, the systematic position of the latter taxon has been briefly discussed (Bayerová \& Haas, 2005; Baruffo et al., 2006; Fehrer et al., 2008; Tretiach et al., 2009; Saag et al., 2009), and a new combination L. jackii var. toensbergiana (Bayerová \& Kukwa) Kukwa has been proposed (Śliwa \& Kukwa, 2012).

Of the species mentioned above, $L$. borealis (granular thallus with delimited thallus and raised lobes), L. bergensis and L. humida (anthraquinones in subthalline hyphae), and $L$. celata (confined to mountainous regions) also produce jackinic/rangiformic or angardianic/ roccellic acids accompanied by atranorin, but grow mostly on siliceous rocks and soil. L. granulata (granulata unknown 1 \& 2), L. jackii var. toensbergiana (toensbergianic acid), L. rigidula (nephrosteranic acid) and L. sylvicola (roccellic and toensbergianic acids) are chemically distinct by producing other fatty acids (see literature cited here).

The identification of fatty acids in our $L$. jackii samples needs further verification using additional solvent systems, e.g. B' and G (Orange et al., 2001); however, TLC in solvent $C$ was repeated at least twice for each specimen and the results were similar and uniform (Bayerová et al., 2005) for 68 samples; one sample was preliminarily identified as $L$. cf toensbergiana and its specific affiliation was verified by Martin Kukwa.

Selected specimens examined: Brest region, Baranovichi district, $1 \mathrm{~km} \mathrm{~N}$ of Baranovichi town, 



Fig. 2. Distribution of Lepraria jackii (A), L. neglecta (B), L. rigidula (C) and L. vouauxii (D) in Belarus.

$53^{\circ} 10^{\prime} \mathrm{N}, 26^{\circ} 00^{\prime} \mathrm{E}, 182 \mathrm{~m}$, spruce forest, on Picea $a b-$ ies, 27.08.2009, leg. P. Bely (MSKH-4665); Gomel region, Gomel district, Dolgolesskoje forest, $0.2 \mathrm{~km} \mathrm{E}$ of Dolgolesie village, $52^{\circ} 16^{\prime} \mathrm{N}, 30^{\circ} 43^{\prime} \mathrm{E}, 120 \mathrm{~m}$, pine forest, on Pinus sylvestris, 07.08.2013, leg. A. Tsurykau (GSU-1865); Grodno region, Novogrudok district, 3 $\mathrm{km}$ NNE of Ponemon' village, $53^{\circ} 40^{\prime} \mathrm{N}, 26^{\circ} 13^{\prime} \mathrm{E}, 139$ m, spruce forest, on Picea abies, 12.09.2010, leg. P. Bely (MSKH-4779); Minsk region, Volozhin district, $2.5 \mathrm{~km}$ E of Malaja Dajnovka, $54^{\circ} 09^{\prime} \mathrm{N}, 26^{\circ} 28^{\prime} \mathrm{E}, 255$ $\mathrm{m}$, spruce forest, on lignum, 24.10.2010, leg. P. Bely (MSKH-5867); Mogilev region, Krichev district, 1.5 $\mathrm{km} \mathrm{W}$ of Sychiki village, 534' $\mathrm{N}, 31^{\circ} 22^{\prime} \mathrm{E}, 187 \mathrm{~m}$, spruce forest, on Pinus sylvestris, 23.07.2011, leg. P. Bely (MSKH-4324); Vitebsk region, Orsha district, $3.5 \mathrm{~km}$ S of Shibeki village, $54^{\circ} 35^{\prime} \mathrm{N}, 29^{\circ} 57^{\prime} \mathrm{E}, 243 \mathrm{~m}$, spruce forest, on Picea abies, 16.06.2011, leg. P. Bely (MSKH-4041).

Number of specimens examined: 69.

\section{LEPRARIA NEGLECTA (Nyl.) Erichsen}

The single specimen of $L$. neglecta housed in MSK was previously studied by Golubkov \& Kukwa (2006); for details see the latter paper. Distributional data are provided in Fig. 2B.

\section{LEPRARIA RIgIDUla (B. de Lesd.) Tønsberg}

Morphology: Thallus leprose, cottony to powdery, whitish or light green, margin diffuse, medulla sometimes present, white, projecting hyphae long. A difference in morphology is often caused by a variety of habitat conditions (Kukwa, 2006b). In Belarus, the terricolous sample is characterized by its rather whitish thallus with well-developed medulla, while the corticolous thallus is thinner and has a greenish colour resembling L. jackii.

Chemistry: Atranorin and nephrosteranic acid.

Ecology: L. rigidula was found growing on soil (1 specimen) and Pinus sylvestris (1) in open habitat and middle-aged pine forest, respectively. In Poland it usually grows on nutrient-rich tree bark in open localities, being rare within forests (Kukwa, 2006b).

Distribution: New to Belarus, being known only from two localities in the Gomel region in the south-eastern part of the country (Fig. 2C). L. rigidula has been reported from Europe, Asia, North and South America, northern Africa and the Antarctic region (Øvstedal \& Lewis Smith, 2001; Flakus \& Kukwa, 2007; Saag et al., 2009; Lendemer, 2013).

Notes: Species producing fatty acids and atranorin are compared under L. jackii.

Specimens examined: Gomel region, Buda-Koshelevo district, Chebotovichi forest, $0.5 \mathrm{~km}$ SW of Klenovitsa village, $52^{\circ} 36^{\prime} \mathrm{N}, 30^{\circ} 19^{\prime} \mathrm{E}, 131 \mathrm{~m}$, pine forest, on Pinus sylvestris, 13.07.2013, leg. A. Tsurykau (GSU); Rechitsa district, close to Unoritsa village, $52^{\circ} 27^{\prime} \mathrm{N}$, $30^{\circ} 19^{\prime} \mathrm{E}, 120 \mathrm{~m}$, bank of the Dnieper river, on soil, 10.08.2008, leg. A. Tsurykau (GSU).

Number of specimens examined: 2 .

LEPRARIA VOUAUXII (Hue) R.C. Harris

Morphology: Thallus leprose, cottony, soft, thick, grey to green, with distinct yellowish tint, thallus margin diffuse, medulla white, soredia loosely packed, with short projecting hyphae.

Chemistry: Pannaric acid 6-methylester.

Ecology: L. vouauxii is a ubiquitous lichen, occurring in natural habitats and in urban areas. The species was found on trees with medium acidic to basic and nutrient-rich bark, namely Acer platanoides, Alnus glutinosa, Fraxinus excelsior, Malus sylvestris and Quercus robur.

Distribution: In Belarus the species is rare, but probably under-collected, being known only from six localities in the southern part of the country (Fig. 2D). L. vouauxii is a cosmopolitan lichen commonly reported from all continents including the Antarctic region (Øvstedal \& Lewis Smith, 2001; Flakus \& Kukwa, 2007; Saag et al., 2009; Lendemer, 2013; McCarthy, 2015). 
Notes: In Belarus L. vouauxii is most similar to L. finkii, but the latter differs by its chemistry, having long projective hyphae, and lacking the yellowish tint. This is the only Lepraria species with pannaric acid 6-methylester known to occur in Belarus.

Selected specimens examined: Brest region, Pruzhany district, Belovezhskaya Pushcha National Park, Pererovo forestry, $2 \mathrm{~km}$ E of Pererovo village, $52^{\circ} 38^{\prime} \mathrm{N}$, $23^{\circ} 55^{\prime} \mathrm{E}, 162 \mathrm{~m}$, black alder forest, on Fraxinus excelsior, 22.06.1983, leg. V. Golubkov (MSK); Gomel region, Zhitkovichi district, Pripyatsky national park, Ozerany forest, $51^{\circ} 59^{\prime} \mathrm{N}, 27^{\circ} 51^{\prime} \mathrm{E}, 127 \mathrm{~m}$, birch forest, on Acer platanoides, 16.06.1971, leg. O. Shakhrai, (GSU-2139); Grodno region, Grodno district, the city of Grodno, Gilibert central park, $53^{\circ} 41^{\prime} \mathrm{N}, 23^{\circ} 50^{\prime} \mathrm{E}$, $122 \mathrm{~m}$, on Fraxinus excelsior, 09.11.2004, leg. A. Tsurykau (GSU-1877).

Number of specimens examined: 11 .

\section{ACKNOWLEDGEMENTS}

We are most grateful to Professor Martin Kukwa (Gdańsk) for his continued support, to Dr Valentina Polyksenova and Svetlana Drobyshevskaja (Minsk) for providing access to the specimens housed in the MSKU herbarium, to Dr Tiina Randlane (Tartu) and an anonymous referee for useful comments on the manuscript, and to Professor Mark R. D. Seaward (Bradford) for his linguistic corrections and other improvements.

\section{REFERENCES}

Baruffo, L., Zedda, L., Elix, J. A. \& Tretiach, M. 2006. A revision of the lichen genus Lepraria s. lat. in Italy. Nova Hedwigia 83: 387-429. http: / / dx.doi. org/10.1127/0029-5035/2006/0083-0387

Bayerová, Š. \& Haas, K. 2005. Toensbergianic acid, a new aliphatic diacid from the genus Lepraria (Ascomycota, Stereocaulaceae). Bryologist 108: 224-227. http://dx.doi.org/10.1639/8

Bayerová, Š., Kukwa, M. \& Fehrer, J. 2005. A new species of Lepraria (lichenized Ascomycetes) from Europe. Bryologist 108: 131-138. http://dx.doi. org/10.1639/0007-2745(2005)108[131:ANSOL L]2.0.CO;2

Bungartz, F., Hillmann, G., Kalb, K. \& Elix, J. A. 2013. Leprose and leproid lichens of the Galapagos, with a particular focus on Lepraria (Stereocaulaceae) and Septotrapelia (Pilocarpaceae). Phytotaxa 150: 1-28. http://dx.doi.org/10.11646/phytotaxa.150.1.1

Czyżewska, K. 2005. Notes on two species of Lepraria from Belarus. Graphis Scripta 17: 20-21.

Ekman, S. \& Tønsberg, T. 2002. Most species of Lepraria and Leproloma form a monophyletic group closely related to Stereocaulon. Mycological Research 106: 1262-1276. http:/ /dx.doi. org/10.1017/S0953756202006718

Fehrer, J., Slavikova-Bayerova, Š. \& Orange, A. 2008. Large genetic divergence of new, morphologically similar species of sterile lichens from Europe (Lepraria, Stereocaulaceae, Ascomycota): concordance of DNA sequence data with secondary metabolites. Cladistics 24: 443-458. http:// dx.doi.org/10.1111/j.1096-0031.2008.00216.x

Flakus, A. \& Kukwa, M. 2007. New species and records of Lepraria (Stereocaulaceae, lichenized Ascomycota) from South America. Lichenologist 39: 463-474. http://dx.doi.org/10.1017/ S0024282907007116

Ges', D. K. 1960. To the studies of Polesje lichens. Proceedings of the Academy of Sciences of the BSSR. Series of Biological Sciences. 4: 54-59 [In Belarusian].

Gilibert, J. E. 1781. Flora lithuanica inchoata, seu Enumeratio plantarum Quas Circa Grodnam coll'egit et determinavit Joannes Emmanuel Gilibert. Grodnae, Typis S.R.M.

Golubkov, V. V. 1988. Botanical justification for the protection of the boulder "Byki". Botany. Research 29: 152-153. [In Russian]

Golubkov, V. V. 2011. Lichen biota of Pripyatsky national park. Minks: Belarusian Publishing House. [In Russian]

Golubkov, V. V. \& Kukwa, M. 2006. A contribution to the lichen biota of Belarus. Acta Mycologica 41: 155-164. http://dx.doi.org/10.5586/ am.2006.019

Golubkov, V. V. \& Shukanov, A. S. 1983. Lichens of "Golubyje ozera" state landscape reserve. Botany. Research 25: 56-67. [In Russian]

Gorbach, N. V. 1973. Lichens of Belarus. A handbook. Minsk, Nauka i Tekhnika [In Russian].

Güvenç Ş. \& Oztürk Ş. 1999. Lichens in the NorthEast regions of Cyprus. Feddes Repertorium 110: 455-463. http://dx.doi.org/10.1002/ fedr. 19991100518

Hodkinson, B. P. \& Lendemer, J. C. 2013. Next-generation sequencing reveals sterile crustose lichen phylogeny. Mycosphere 4: 1028-1039.

Kharpukhaeva, T. M. \& Khanin V. A. 2012. New for Republic of Buryatia species of Lepraria identified by HPLC. Turczaninowia 15(4): 44-47.

Kukwa, M. 2006a. Notes on taxonomy and distribution of the lichen species Lepraria ecorticata comb. nov. Mycotaxon 97: 63-66.

Kukwa, M. 2006b. The lichen genus Lepraria in Poland. Lichenologist 38: 293-305. http://dx.doi. org/ 10.1017/S0024282906005962

Kukwa, M. \& Flakus, A. 2009. Lepraria glaucosorediata sp. nov. (Stereocaulacae, lichenized Ascomycota) and other interesting records of Lepraria. Mycotaxon 108: 353-364. http:/ /dx.doi. org/10.5248/108.353 
Laundon, J. R. 1992. Lepraria in the British Isles. Lichenologist 24: 315-350.

Lendemer, J. C. 2010. Notes on the genus Lepraria s.1. (lichenized ascomycetes) in North America: new species, new reports, and preliminary keys. Brittonia 62: 267-292. http://dx.doi.org/10.1007/ s12228-010-9142-4

Lendemer, J. C. 2011. A taxonomic revision of the North American species of Lepraria s.1. that produce divaricatic acid, with notes on the type species of the genus L. incana. Mycologia 103: 1216-1229. http:/ /dx.doi.org/ 10.3852/11-032

Lendemer, J. C. 2013. A monograph of the crustose members of the genus Lepraria Ach. s. str. (Stereocaulaceae, Lichenized Ascomycetes) in North America north of Mexico. Opuscula Philolichenum 11: 27-141.

Lendemer, J. C. \& Hodkinson, B. P. 2013. A radical shift in the taxonomy of Lepraria s.1.: Molecular and morphological studies shed new light on the evolution of asexuality and lichen growth form diversification. Mycologia 105: 994-1018. http:// dx.doi.org/ 10.3852/12-338

Leuckert, C., Kümmerling, H. \& Wirth, W. 1995. Chemotaxonomy of Lepraria Ach. and Leproloma $\mathrm{Nyl}$ ex. Crombie, with particular reference to Central Europe. Bibliotheca Lichenologica 58: 245-259.

Lohtander, K. 1994. The genus Lepraria in Finland. Annales Botanici Fennici 31: 223-231.

McCarthy, P. M. 2015. Checklist of the Lichens of Australia and its Island Territories. Australian Biological Resources Study, Canberra. Version 10 December 2015. http: / /www.anbg.gov.au/abrs / lichenlist/introduction.html

Mežaka, A. Brūmelis, G., Piterāns, A. \& Printzen, C. 2012. Distribution of Lepraria in Latvia in relation to tree substratum and deciduous forest type. Annales Botanici Fennici 49(3): 162-170. http:/ / dx.doi.org/10.5735/085.049.0302

Nelsen, M. P., Lumbsch, H. T., Lücking, R. \& Elix, J. A. 2008. Further evidence for the polyphyly of Lepraria (Lecanorales: Stereocaulaceae). Nova Hedwigia 87: 361-371. http://dx.doi. org/10.1127/0029-5035/2008/0087-0361

Orange, A., James, P. W. \& White, F. J. 2001. Microchemical Methods for the Identification of Lichens. British Lichen Society, London. 101 pp.

Øvstedal, D. O. \& Lewis Smith, R. I. 2001. Lichens of Antarctica and South Georgia. A guide to their identification and ecology. Cambridge University Press, Cambridge. $411 \mathrm{pp}$.

Poelt, J. 1958. Systematik der Flechten. Bericht über die Jahre 1956 und 1957 mit einigen Nachträgen. Fortschritte der Botanik 20: 56-62. http: / / dx.doi. org/10.1007/978-3-642-85743-0_7
Reichenbach, H. G. L. 1841. Der Deutsche Botaniker. Erster Band. Das Herbarienbuch. Dresden \& Leipzig: Arnoldischen Buchhandlung.

Saag, L., Saag, A. \& Randlane, T. 2009. World survey of the genus Lepraria (Stereocaulaceae, lichenized Ascomycota). Lichenologist 41: 25-60. http:// dx.doi.org/10.1017/S0024282909007993

Sipman, H. J. M. 2003. New species of Cryptothecia, Lepraria, and Ocellularia (lichenized Ascomycetes) from Singapore. Bibliotheca Lichenologica 86: $177-184$.

Sipman, H. J. M. 2004. Survey of Lepraria with lobed thallus margins in the tropics. Herzogia 17: 23-35.

Slavíková-Bayerová, Š \& Fehrer, J. 2007. New species of the Lepraria neglecta group (Stereocaulaceae, Ascomycota) from Europe. Lichenologist 39: 319-327. http://dx.doi.org/10.1017/ S0024282907006688

Slaviková-Bayerová, Š. \& Orange, A. 2006. Three new species of Lepraria (Ascomycota, Stereocaulaceae) containing fatty acids and atranorin. Lichenologist 38: 503-513. http://dx.doi.org/10.1017/ S0024282906006177

Śliwa, L. \& Kukwa M. 2012. New distribution data for sterile crustose lichens in the Polish Tatra Mts and its surroundings. Polish Botanical Journal 57: 259-278.

Tehler, A. 1996. Systematics, phylogeny and classification. In: Nash III, T. H. (ed). Lichen Biology. Cambridge: Cambridge University Press.

Thiers, B. [continuously updated]. Index Herbariorum: A global directory of public herbaria and associated staff. New York Botanical Garden's Virtual Herbarium. http://sweetgum.nybg.org/ih/

Tønsberg, T. 1992. The sorediate and isidiate, corticolous, crustose lichens in Norway. Sommerfeltia 14: $1-331$.

Tønsberg, T. 2002. Notes on non-corticolous Lepraria s. lat. in Norway. Graphis Scripta 14: 45-51.

Tretiach, M., Muggia, L. \& Baruffo, L. 2009. Species delimitation in the Lepraria isidiata - L. santosii group: a population study in the MediterraneanMacaronesian region. Lichenologist 41: 1-15. http://dx.doi.org/10.1017/S0024282909008093

Tsurykau, A., Golubkov, V. \& Kukwa, M. 2014. New or otherwise interesting records of lichens and lichenicolous fungi from Belarus. Herzogia. 27: 111-120. http://dx.doi.org/10.13158/ heia.27.1.2014.111

Urbanavichus, G. P. 2010. A checklist of the lichen flora of Russia. St Petersburg: Nauka. 